\title{
Studies on the reaction sintered zirconia-mullite-alumina composites with titania as additive
}

\section{(Estudos de compósitos zircônia-mulita-alumina sinterizados por reação com titânia como aditivo)}

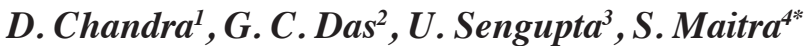 \\ ${ }^{1}$ OCL India Limited, Rajgangpur, Orissa, India \\ ${ }^{2}$ Dept. of Metallurgical Engineering, Jadavpur University, Kolkata, India \\ ${ }^{3}$ Refratechnik Steel GmbH, Vishakhapatnam, India \\ ${ }^{4}$ Govt. College of Engineering and Ceramic Technology, Kolkata, India \\ debabehala@rediffmail.com,gopesdas@yahoo.co.in,senguptaujjwal@yahoo.com, \\ *corresponding author: maitrasaikat@rediffmail.com
}

\begin{abstract}
Zirconia-mullite-alumina composites were prepared by reaction sintering of micro fine calcined alumina and zircon flour in different ratios. $\mathrm{TiO}_{2}$ was added in different proportions as an additive and the starting materials were iso-statically pressed. $\mathrm{The}_{2} \mathrm{Al}_{2} / \mathrm{ZrO}_{2}$ ratios and the proportions of the $\mathrm{TiO}_{2}$ additive content were found to influence the physico-mechanical properties of the compacts significantly. The fabricated compacts exhibited exceptionally high sintered density, mechanical strength and corrosion resistance. From the micro-structural analysis of the sintered compacts it has been observed that the relative size of the $\mathrm{ZrO}_{2}$ grains and relative proportion of $\mathrm{t}-\mathrm{ZrO}_{2}$ phase in the batches with $\mathrm{TiO}_{2}$ additive was more compared to batches without $\mathrm{TiO}_{2}$ additive.
\end{abstract}

Keywords: zirconia-mullite, reaction sintering, $\mathrm{TiO}_{2}$ additive, iso-static pressing, corrosion resistance.

Resumo

Compósitos de zircônia-mulita-alumina foram preparados por sinterização com reação de alumina micro fina calcinada e zircão em diferentes proporções. TiO ${ }_{2}$ foi adicionado em diferentes proporções como aditivo, e os matérias de partida foram prensados isostaticamente. As proporções de $\mathrm{Al}_{2} \mathrm{O}_{3} / \mathrm{ZrO}_{2}$ com teores significativos do aditivo adicionado TiO foram encontrados para influenciar nas propriedades físico-mecânicas dos compactos. Os compactos sinterizados apresentaram alta densidade, resistência mecânica e resistência à corrosão. Na análise micro estrutural dos compactos foi observado que o tamanho relativo dos grãos de $\mathrm{ZrO}_{2}$ e a fase $\mathrm{t}-\mathrm{ZrO}_{2}$ no lote com aditivo $\mathrm{TiO}_{2}$ foi comparada com as amostras do lote sem aditivo $\mathrm{TiO}_{2}$.

Palavras-chave: zircônia-mulita, reação de sinterização, aditivo $\mathrm{TiO}_{2}$, pressão isostática, resistência à corrosão.

\section{INTRODUCTION}

Mullite and mullite-alumina composite matrices with another dispersed phase like zirconia have been widely used for high-temperature applications for their different superior physico-mechanical properties [1]. Both the flexural strength and fracture toughness values of zirconia-mullite composites are more than alumina and mullite composites [2]. Mullitezirconia composites find different technically challenging important applications due to their several superior physicomechanical properties, like, toughness, chemical stability and high-creep resistance. They are also employed in the glass industry where a high level of corrosion resistance is required. Zircon flour and alumina powders are largely employed as raw materials in the manufacturing of this important composite [3-7]. For the preparation of zirconia-mullite composites, reaction sintering route has gained much attention due to the availability of the starting materials and the lower processing temperature required. Many works have been reported on the reaction sintering of zirconia-mullite composites and some of these are mentioned below. Das and Banerjee [8] prepared reaction sintered zirconia-mullite composites using zircon flour, alumina and dysprosia as sintering additive. Nicolas et al. [9] used two different processing routes: for the preparation of zirconia-mullite composites, which are reaction sintering of alumina and zircon and direct sintering of mullite-zirconia grains by slip casting and sintered at 1600 ${ }^{\circ} \mathrm{C}$ for $2 \mathrm{~h}$. Ozturk [10] prepared textured mullite-zirconia composites preparation from a reactive mixture of alumina and zircon powders together with acicular aluminum borate templates to nucleate and texture mullite grains in the [001]. Ebadzadeh and Ghasemi [11] prepared zirconia-mullite composites using $\alpha$-alumina and aluminium nitrate and zircon powder with $\mathrm{TiO}_{2}$ as additive. Das et al. [12] synthesized 
mullite-zirconia composites containing yttria as additive from Indian coastal zircon flour and calcined alumina. Melo et al. [13] prepared zirconia-toughened ceramics with a mullite matrix based on the quaternary system $\mathrm{ZrO}_{2}-\mathrm{Al}_{2} \mathrm{O}_{3}-\mathrm{SiO}_{2}$ $\mathrm{TiO}_{2}$ in the temperature range $1450-1550{ }^{\circ} \mathrm{C}$ using zirconalumina-titania mixtures. Maitra et al. [14] reported semicolloidal technique to synthesize a precursor powder for zirconia-mullite composites using an aqueous suspension of sillimanite powder and zirconium oxy-chloride solution and adding micron sized aluminium powder to the precipitate to form incipiently formed alumina by oxidation during heat treatment.

In the present work reaction sintered zirconia-mullite composites were prepared from isostatically pressed zircon flour and calcined alumina powder. $\mathrm{TiO}_{2}$ was used as an additive and the sintered compacts were characterized by the measurement different physico-mechanical parameters like, bulk density, apparent porosity, specific gravity, MOR, HMOR, MOE, hardness, abrasion resistance and corrosion resistance. Microstructure and phase analyses of the compacts were carried out by XRD, SEM and EDX analyses to ascertain the influence of process parameters on the properties of the compacts.

\section{EXPERIMENTAL}

Micro-fine (-325 mesh) calcined alumina $\left(98 \% \mathrm{Al}_{2} \mathrm{O}_{3}\right)$ of ALCOA and zircon flour (-170 mesh) from Indian Rare Earth Ltd (IREL) were used as starting materials. Microfine titania powder was used as an additive. The physico-chemical properties of the starting materials are given (Table I). The particle sizes and surface area of all the starting materials have been analyzed (Table II) following ASTM C92-95 specification. The ingredients were mixed in different proportions and the batch compositions are detailed (Table III). Specific gravity (Table IV) of the starting raw materials have also been computed following the procedure given in IS 1528, Part IX, 1980. The powders were mixed in a dry mixer with the required amount of organic binder and moisture for better workability during pressing. The mixes were compacted by isostatic pressing at 1500 bar (holding time 12 min). These compacted specimens were dried at $(105 \pm 5){ }^{\circ} \mathrm{C}$ for $24 \mathrm{~h}$ and sintered at $1550{ }^{\circ} \mathrm{C}$ for $2.5 \mathrm{~h}$. Different physicomechanical properties of the sintered specimens like bulk density, apparent porosity, specific gravity, MOR, HMOR, MOE, hardness were measured following ASTM C 830-00, IS 1528, Part IX, 1980, ASTM C133-97, ASTM 583 C1983, ASTM C885-97 and DIN 52108 specifications, respectively. Abrasion resistance and corrosion resistance of the test samples were carried out following standard procedures. The phase compositions in the sintered specimens were ascertained with XRD analyses using a diffractometer (Philips, PW 1383) with Cuk $\alpha$ radiation. Phase distributions in the sintered compacts (polished sections) were analyzed with an optical microscope (Leitz, Germany, labour Lux 12MEST) followed by SEM and EDEX analysis by carbon coating (Format- JEOL/EO, version 1.1, model JSM-6480).
Table I - Chemical analysis of raw materials. [Tabela I - Análise química das matérias-primas.]

\begin{tabular}{cccc}
\hline $\begin{array}{c}\text { Constituent } \\
(\text { mass \%) }\end{array}$ & $\begin{array}{c}\text { Calcined } \\
\text { Alumina }\end{array}$ & $\begin{array}{c}\text { Zircon } \\
\text { Flour }\end{array}$ & $\begin{array}{c}\text { Titania } \\
\text { Powder }\end{array}$ \\
\hline $\mathrm{Al}_{2} \mathrm{O}_{3}$ & 97.61 & - & - \\
$\mathrm{TiO}_{2}$ & 0.24 & - & 97.29 \\
$\mathrm{Fe}_{2} \mathrm{O}_{3}$ & 0.16 & - & 1.5 \\
$\mathrm{SiO}_{2}$ & 0.19 & 32.5 & 0.8 \\
$\mathrm{ZrO}_{2}$ & - & 65.2 & - \\
\hline
\end{tabular}

Table II - Particle size analysis of the raw materials. [Tabela II - Tamanho de partícula das matérias primas.]

\begin{tabular}{lcc}
\hline raw material & $\begin{array}{c}\text { mean particle } \\
\text { size }(\mu \mathrm{m})\end{array}$ & $\begin{array}{c}\text { spec surface } \\
\text { area }(\mathrm{sq} . \mathrm{m} / \mathrm{cc})\end{array}$ \\
\hline Alumina & 0.512 & 14.16 \\
Zircon flour & 369.016 & 0.19 \\
Titania powder & 0.831 & 13.34 \\
\hline
\end{tabular}

Table III - Batch composition of the samples. [Tabela III - Composição dos lotes de amostras.]

\begin{tabular}{ccc}
\hline $\begin{array}{l}\text { Batch } \\
\text { No. }\end{array}$ & $\begin{array}{c}\text { Zircon Flour: } \\
\text { Calcined Alumina } \\
\text { (mass ratio) }\end{array}$ & $\begin{array}{c}\mathrm{TiO}_{2} \text { additive } \\
\text { (mass } \%)\end{array}$ \\
\hline & & 2.5 \\
1 & $1: 4$ & 5.0 \\
& & 7.5 \\
& & 10.0 \\
& & 2.5 \\
2 & $1: 5$ & 5.0 \\
& & 7.5 \\
& & 10.0 \\
3 & & 2.5 \\
& & 5.0 \\
& & 7.5 \\
& & 10.0 \\
\hline
\end{tabular}

Table IV - Specific gravity of raw materials. [Tabela IV - Gravidade específica das matérias-primas.]

\begin{tabular}{lc}
\hline \multicolumn{1}{c}{ Materials } & Sp. Gr. \\
\hline Zircon flour & 4.57 \\
Calcined alumina & 3.84 \\
Titania Powder & 4.22 \\
\hline
\end{tabular}

\section{RESULTS AND DISCUSSION}

It is apparent from the $\mathrm{ZrO}_{2}-\mathrm{Al}_{2} \mathrm{O}_{3}-\mathrm{SiO}_{2}$ ternary phase diagram (Fig. 1) that the refractoriness of all the batches was more than $2100{ }^{\circ} \mathrm{C}$. 


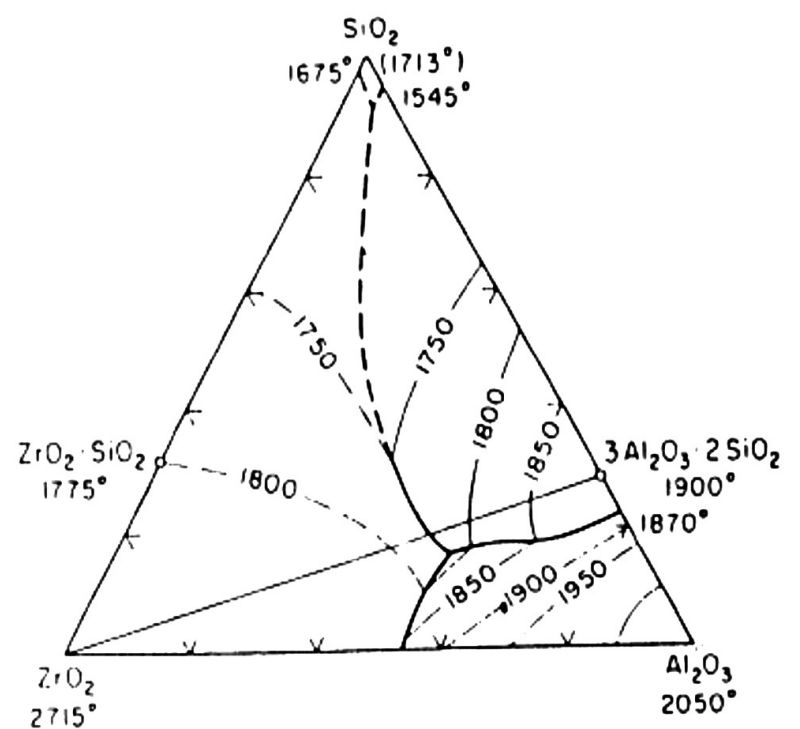

Figure 1: Phase equilibrium diagram of $\mathrm{ZrO}_{2}-\mathrm{Al}_{2} \mathrm{O}_{3}-\mathrm{SiO}_{2}$ for Liquidus Projn [18, 19].

[Figura 1: Diagrama de fases do $\mathrm{ZrO}_{2}-\mathrm{Al}_{2} \mathrm{O}_{3}-\mathrm{SiO}_{2}$ para prokj. liquidus [18, 19].]

During the sintering process the reaction between zircon flour and calcined alumina takes place in the following way,

$3 \mathrm{Al}_{2} \mathrm{O}_{3}+2 \mathrm{ZrSiO}_{4}=\left(3 \mathrm{Al}_{2} \mathrm{O}_{3}, 2 \mathrm{SiO}_{2}\right)+2 \mathrm{ZrO}_{2}+$ Extra Phase (A)

The formation of a glassy phase $\left(\mathrm{SiO}_{2}\right)$ may improve the densification through liquid phase sintering [15]. In conventional reaction sintering methods without much compaction pressure densified mass is difficult to obtain due to the relatively lower bulk and grain boundary diffusion coefficient of mullite and its higher processing temperatures (up to $1600-1650{ }^{\circ} \mathrm{C}$ ) [16]. Therefore, to develop extremely tough mullite matrix composites with excellent flexural strength relatively high compaction pressure and sintering temperature is required.

In presence of $\mathrm{TiO}_{2}$ a quaternary phase system $\mathrm{ZrO}_{2}-$ $\mathrm{Al}_{2} \mathrm{O}_{3}-\mathrm{SiO}_{2}-\mathrm{TiO}_{2}$ is generated. Fig. 2 shows the compatibility relationships of this quaternary system and the projection from the zirconia corner on to the opposite face of the composition tetrahedron. According to the system $\mathrm{ZrO}_{2}-\mathrm{Al}_{2} \mathrm{O}_{3}-\mathrm{SiO}_{2}-\mathrm{TiO}_{2}$ the compositions studied were located in the sub-solidus compatibility plane zirconia-mullite-aluminum-titanate (Fig. 2), i.e., titania solid solution region of zirconia, as defined by the equation:

$$
\begin{aligned}
& 2 \mathrm{ZrSiO}_{4}+3 \mathrm{Al}_{2} \mathrm{O}_{3}+x\left(\mathrm{Al}_{2} \mathrm{O}_{3}+\mathrm{TiO}_{2}\right)= \\
& 2 \mathrm{ZrO}_{2}+\mathrm{Al}_{6} \mathrm{Si}_{2} \mathrm{O}_{13}+x \mathrm{Al}_{2} \mathrm{TiO}_{5}(0.25>\mathrm{x}>1.0)
\end{aligned}
$$

and consequently the initial liquid formation takes place at $1445{ }^{\circ} \mathrm{C}$. Where analyzing in details, this reaction can be parted in two parallel reactions yielding a transitory liquid phase which gradually precipitate out to solid solutions for low titania batches or left as it is for higher titania batches [14].
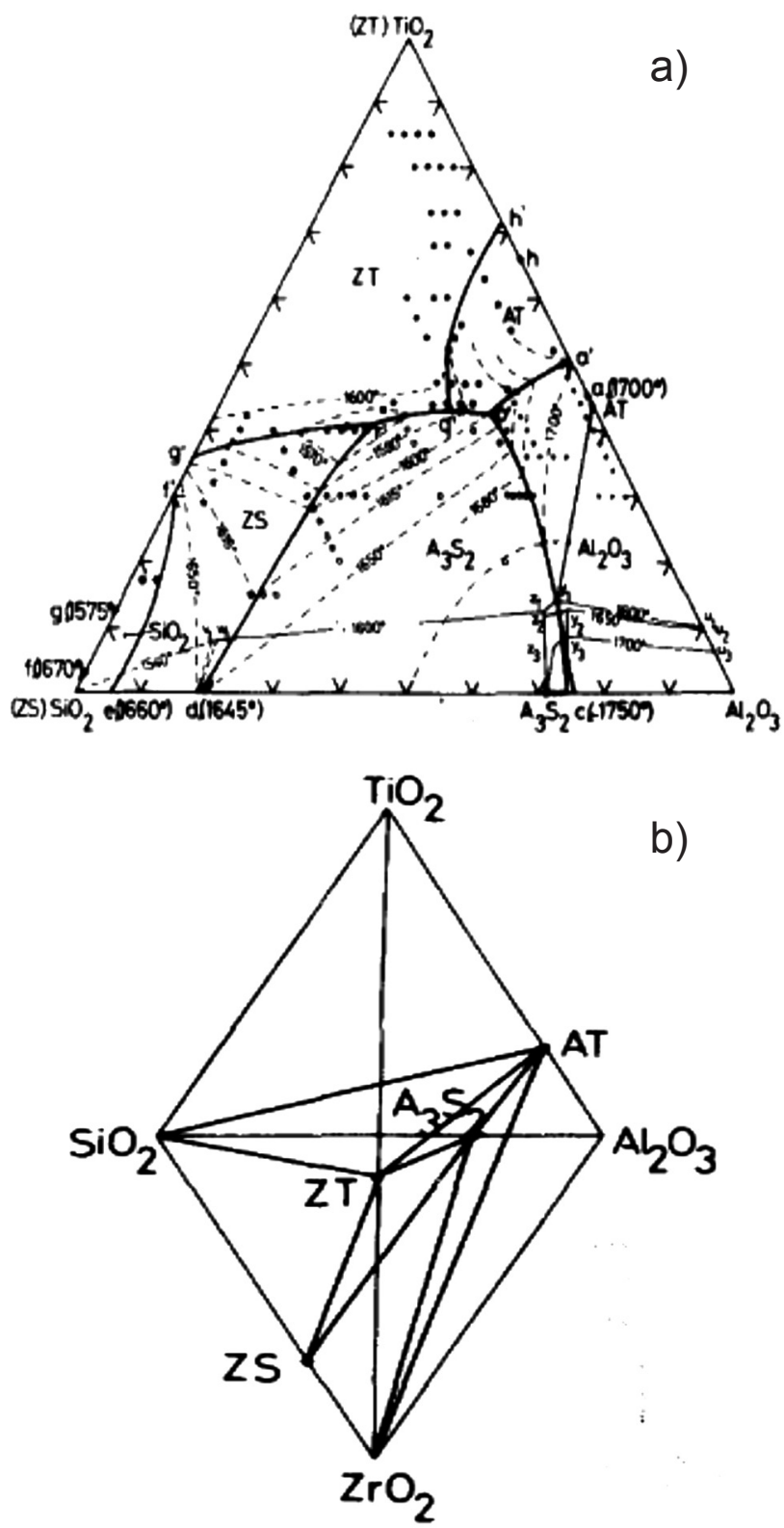

Figure 2: Solid-state compatibility relationships in the $\mathrm{ZrO}_{2}-\mathrm{Al}_{2} \mathrm{O}_{3}$ $\mathrm{SiO}_{2}-\mathrm{TiO}_{2}$ system; and projection through the $\mathrm{ZrO}_{2}$ corner showing secondary phases crystallizing during freezing from $\mathrm{ZrO}_{2}-\mathrm{Al}_{2} \mathrm{O}_{3}-$ $\mathrm{SiO}_{2}-\mathrm{TiO}_{2}$ mixtures [13].

[Figura 2: Relações de compatibilidade de estado sólido no sistema $\mathrm{ZrO}_{2}-\mathrm{Al}_{2} \mathrm{O}_{3}-\mathrm{SiO}_{2}-\mathrm{TiO}_{2}$; e projeção através do vértice de $\mathrm{ZrO}_{2}$, mostrando fases secundárias cristalizando durante congelamento das misturas from $\mathrm{ZrO}_{2}-\mathrm{Al}_{2} \mathrm{O}_{3}-\mathrm{SiO}_{2}-\mathrm{TiO}_{2}$ [13].]

$2 \mathrm{ZrSiO}_{4}+4 \mathrm{Al}_{2} \mathrm{O}_{3}+\mathrm{TiO}_{2}=$

$\mathrm{ZrO}_{2}+\mathrm{Al}_{6} \mathrm{Si}_{2} \mathrm{O}_{13}+\mathrm{ZrTiO}_{4}+\mathrm{Al}_{2} \mathrm{O}_{3}+$

Transient liquid phase

$\mathrm{Al}_{6} \mathrm{Si}_{2} \mathrm{O}_{13}+\mathrm{ZrO}_{2}+\mathrm{ZrTiO}_{4}+\mathrm{Al}_{2} \mathrm{O}_{3}$

+ Transient liquid phase $=\left(\mathrm{Al}_{6} \mathrm{Si}_{2} \mathrm{O}_{13}\right)_{\mathrm{ss}}+$

$\left(\mathrm{ZrO}_{2}\right)_{\mathrm{ss}}+\mathrm{Al}_{2} \mathrm{TiO}_{5}$

Zircon dissociates to yield $\mathrm{ZrO}_{2}$ and amorphous $\mathrm{SiO}_{2}$ on heating. The amorphous $\mathrm{SiO}_{2}$ softens with increasing 

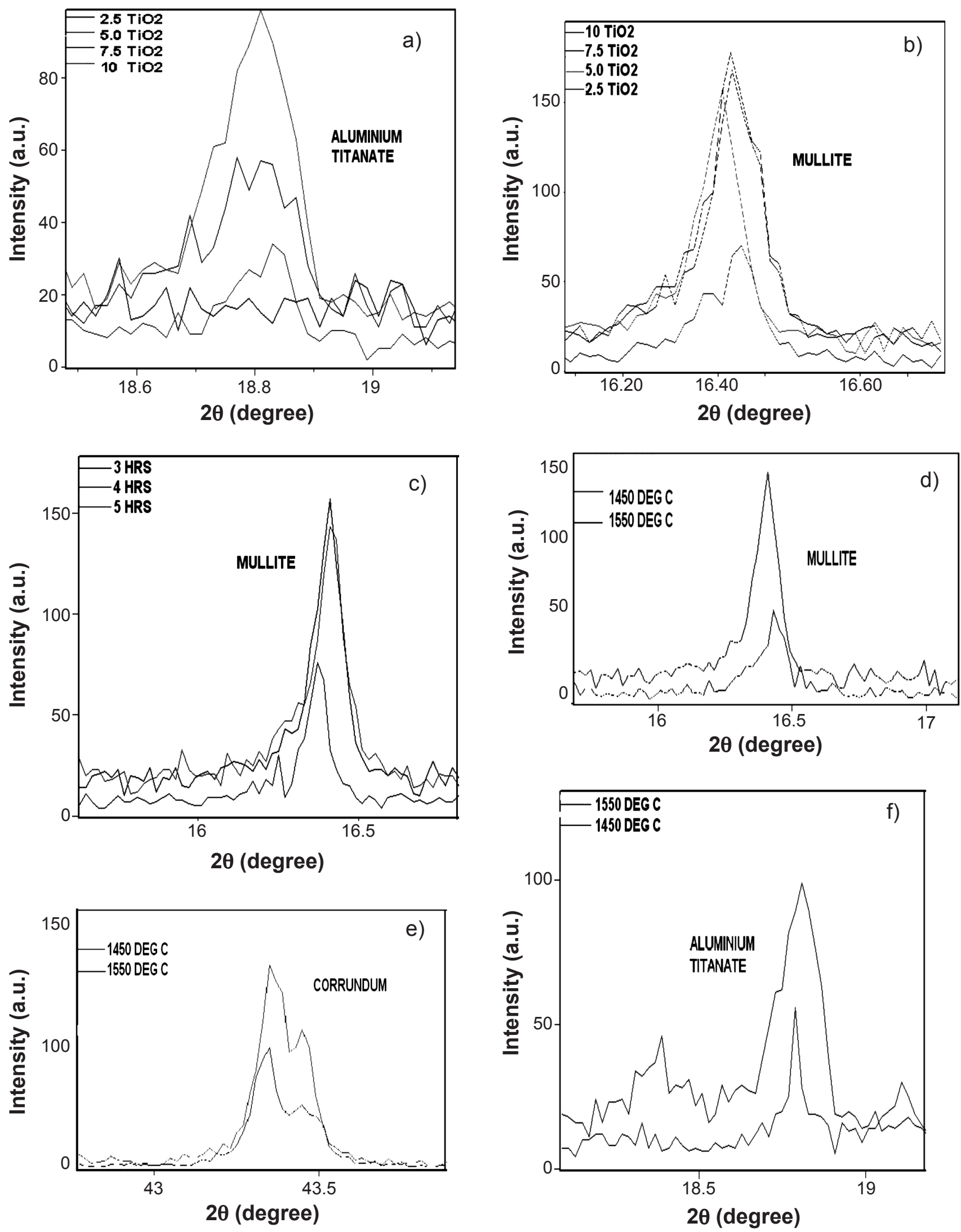

Figure 3: Variation in formation of (A) and (B) - Aluminium titanate and mullite at $1550{ }^{\circ} \mathrm{C}$ with additive, (C) - Aluminium titanate and mullite at $1550{ }^{\circ} \mathrm{C}$ with soaking time, (D), (E) and (F) - mullite, corundum and aluminum titanate at $1550{ }^{\circ} \mathrm{C}$ and $1450{ }^{\circ} \mathrm{C}$ with additive. [Figura 3: Variação na formação de $(A)$ e (B) - Titanato de alumina e mulita a $1550^{\circ} \mathrm{C}$ com aditivo, (C) - Titanato de alumina e mulita a $1550^{\circ} \mathrm{C}$ com tempo de imesrão, $(D),(E)$ e $(F)$ - Mulita, corindum e titanato de alumina em $1550{ }^{\circ} \mathrm{C}$ e $1450{ }^{\circ} \mathrm{C}$ com aditivo.] 
temperature and starts to dissolve $\mathrm{Al}_{2} \mathrm{O}_{3}$ to form an amorphous alumino-silicate glass. Nucleation of mullite takes place after a critical alumina concentration is exceeded in the glass phase. Controlling the yield of ZT with controlled amount of $\mathrm{TiO}_{2}$ addition successfully results in the formation of the grains of zirconia and corundum at high temperature and also allows formation and growth of mullite considerably. Thus enhancement of properties takes place initially.

From the XRD analysis of batch- 1 fired in $1450{ }^{\circ} \mathrm{C}$ and $1550{ }^{\circ} \mathrm{C}$ for 3 to 5 h (Fig. 3) it was observed that mullite formation was facilitated by titania addition. With the increase in temperature and additive mullite formation

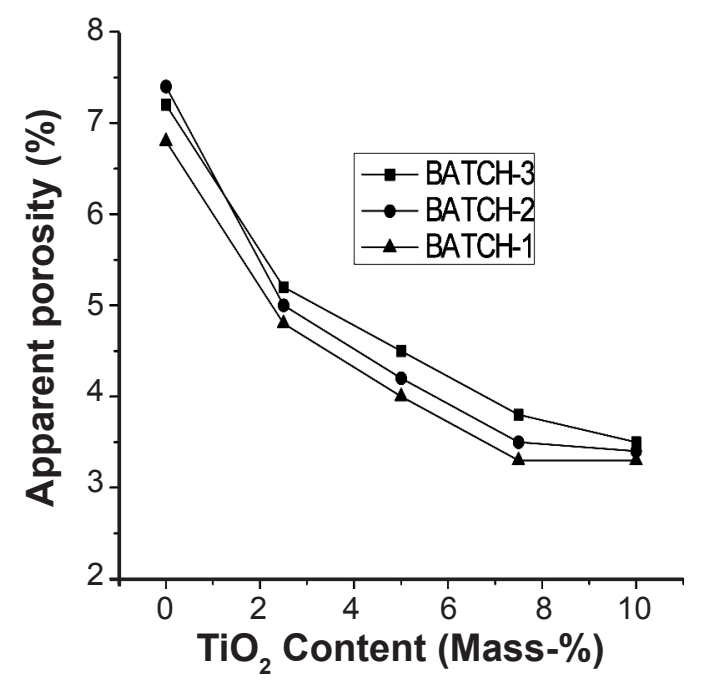

Figure 4: Variation of A.P. (\%) for the compacts.

[Figura 4: Variação de A.P. (\%) para os compactos.]

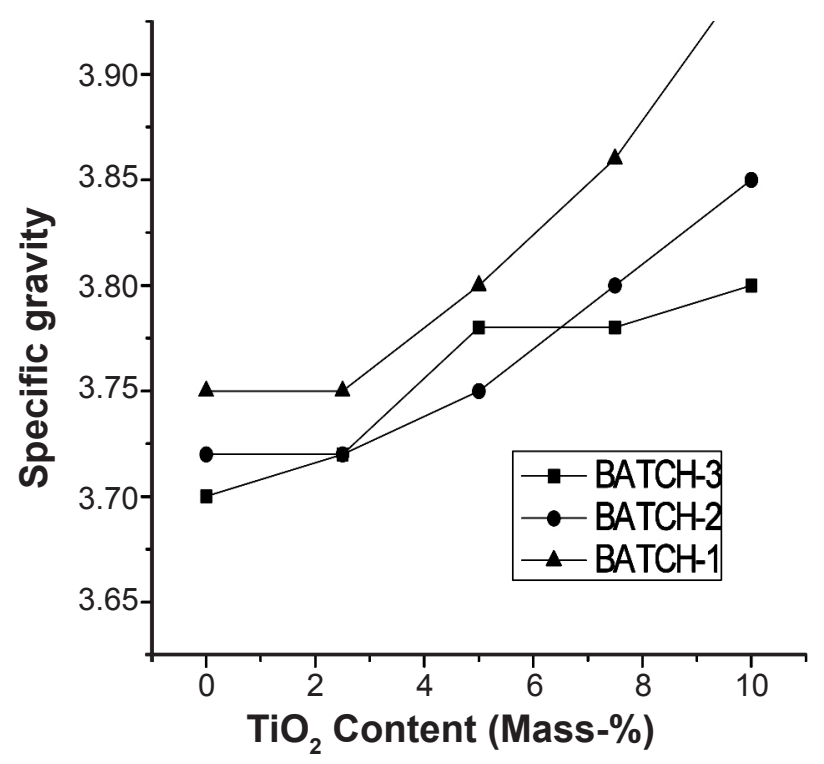

Figure 6: Variation of Sp. Gr. for the compacts.

[Figura 6: Variação do Sp. Gr. para os compactos.] enhanced. Again, $\mathrm{Al}_{2} \mathrm{TiO}_{5}$ phase was identified, which increased with the addition of titania additive and soaking time as well. aluminum-titanate appeared in smaller amount at lower temperature. With the increase in the $\mathrm{Al}_{2} \mathrm{O}_{3}$ content, the proportion of mullite phase increased in the batches.

The isostatically pressed samples exhibited high compactness as evident from their low apparent porosity after heat treatment (Fig. 4). For a particular alumina-zircon ratio apparent porosity was reduced drastically in batches with higher additive content confirming the formation of liquid phase in larger amount. Bulk density of the samples was also changed in the same way (Fig. 5). Substantially

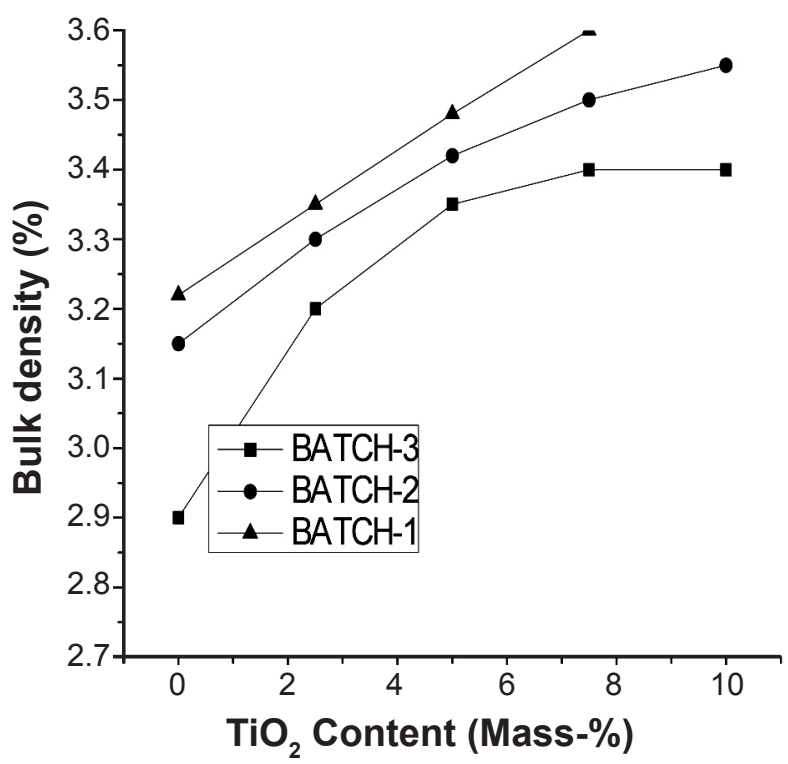

Figure 5: Variation of B.D. $\left(\mathrm{g} / \mathrm{cm}^{3}\right)$ for the compacts.

[Figura 5: Variação de B.D. $\left(\mathrm{g} / \mathrm{cm}^{3}\right)$ para os compactos.]

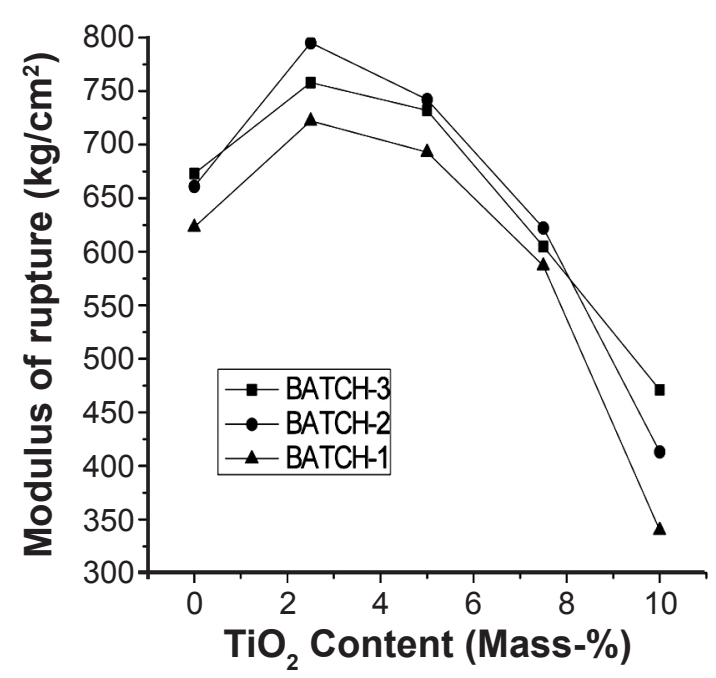

Figure 7: Variation of M.O.R. $\left(\mathrm{kg} / \mathrm{cm}^{2}\right)$ for the compacts. [Figura 7: Variação do M.O.R. $\left(\mathrm{kg} / \mathrm{cm}^{2}\right)$ para os compactos.] 


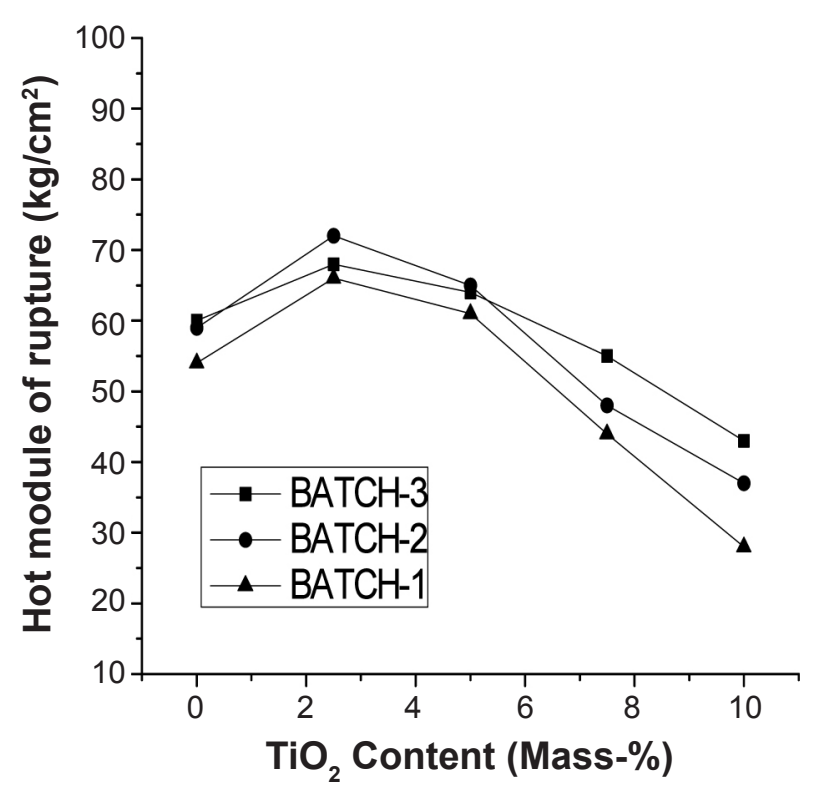

Figure 8: Variation of HMOR $\left(\mathrm{kg} / \mathrm{cm}^{2}\right)$ for the compacts. [Figura 8: Variação do HMOR $\left(\mathrm{kg} / \mathrm{cm}^{2}\right)$ para os compactos.]

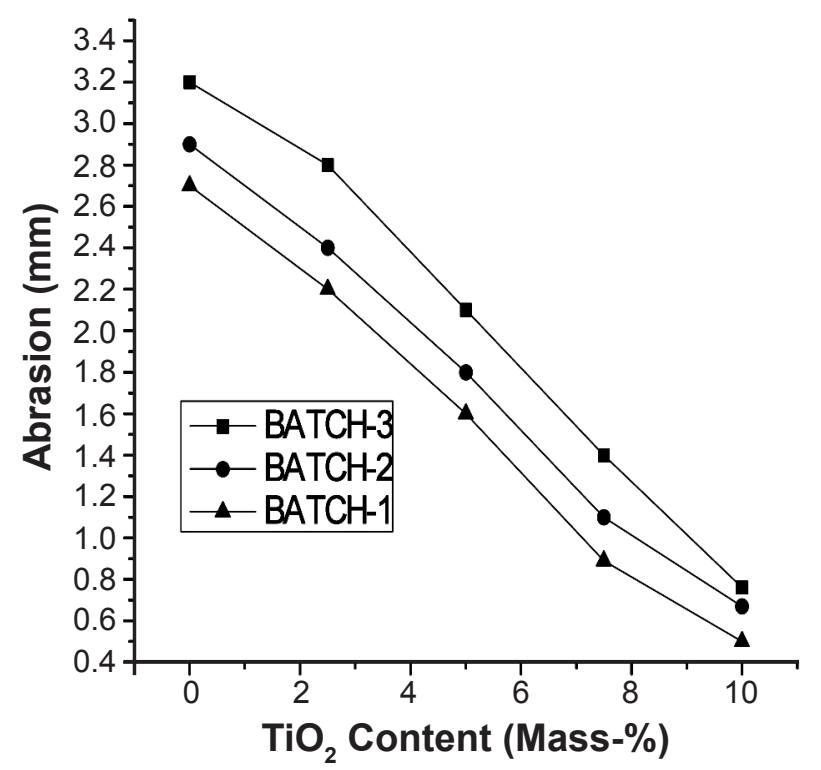

Figure 10: Variation of abrasion loss (thickness) for the compacts. [Figura 10: Variação da perda de abrasão (espessura) para os compactos.]

high value of specific gravity in the sintered compacts was achieved (Fig. 6) here and it increased with titania content for a particular batch. It could be related to the influence of relatively higher specific gravity of $\mathrm{TiO}_{2}$ itself.

The composites exhibited excellent modulus of rupture as well as hot modulus of rupture values (Figs. 7 and 8). The development of a high modulus of rupture in all the samples can be related to the lesser porosity in the samples, which improved also the modulus of elasticity of the samples. With the increase in the proportion of alumina the modulus of rupture and elasticity values increased. This might be related to the formation of more inter-locked

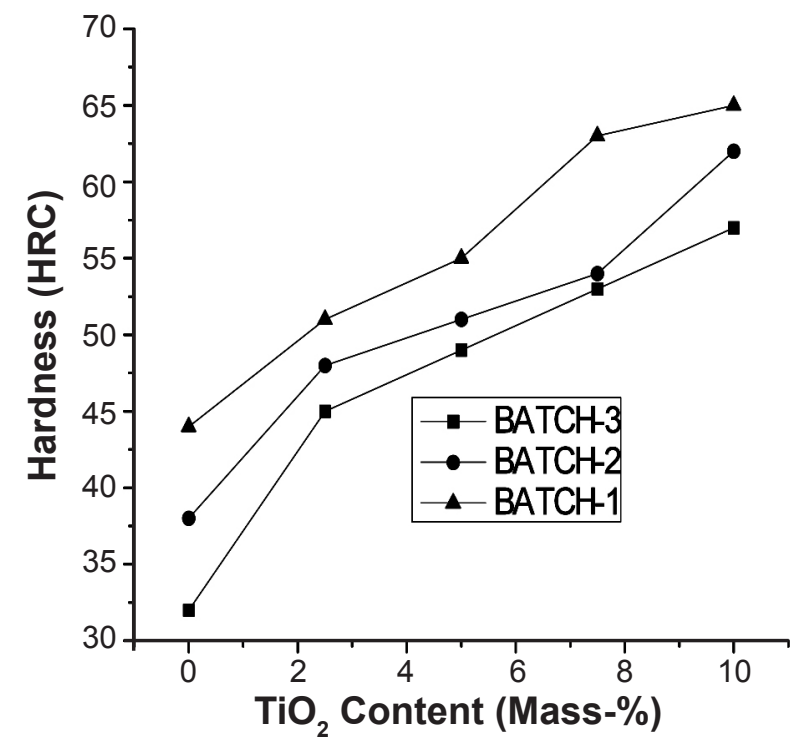

Figure 9: Variation of hardness for the compacts.

[Figura 9: Variação da dureza para os compactos.]

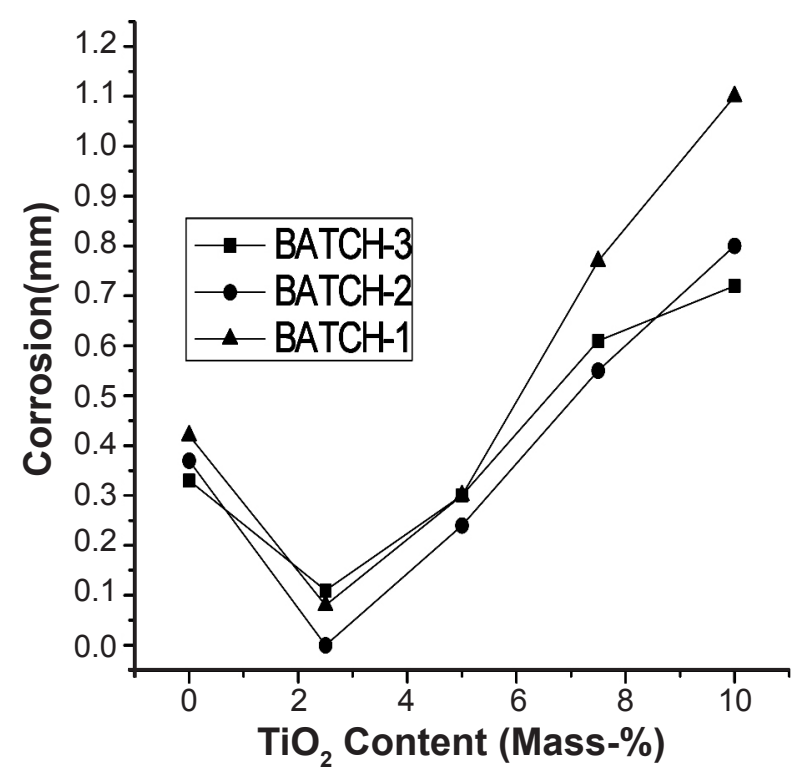

Figure 11: Variation of loss in corrosion (thickness) for the compacts.

[Figura 11: Variação da perda na corrosão (espessura) para os compactos.]

mullite and less zirconia-transformation-induced strain in the microstructure. With the increase in $\mathrm{TiO}_{2}$ content, the modulus of rupture values decreased slightly, which could be related to the presence of higher aluminum-titanate formation in the structure which reduced the interlocking of the mullite crystals to some extent. With the addition of 2-3.5 parts of $\mathrm{TiO}_{2}$ additive in the batches the strengths and related parameters of the composites improved significantly.

The hardness of the samples in Moh's scale was found to be above seven (Fig. 9). The hardness values of the samples increased with the increase in the proportion of alumina in the batches. For a particular batch, the hardness increased with 
the increase in the $\mathrm{TiO}_{2}$ additive content. It can be related to the formation of more corundum and mullite phases in the microstructure. As a result of improved hardness the samples exhibited exceptional abrasion resistance (Fig. 10). Even after 16 cycles of abrasion the loss in thickness in the samples was observed to be negligible.

The compacts were tested against a synthetic slag (here molten soda-lime-silicate glass were used), to asses their corrosion resistance behaviors. A drum test was conducted at $1500{ }^{\circ} \mathrm{C}$ with 4 taps (each tap was done after $20 \mathrm{~min}$ ). The chemical composition of the slag was like the following, $\mathrm{SiO}_{2}-71 \%, \mathrm{Na}_{2} \mathrm{O}-8.7 \%, \mathrm{CaO}-14.6 \%, \mathrm{SO}_{3}-0.7 \%, \mathrm{MgO}$ and $\mathrm{Fe}_{2} \mathrm{O}_{3}-2.1 \%$, other alkalis $-2.9 \%$. All the samples exhibited exceptional corrosion resistance. Corrosion (loss in thickness) of the samples after the Rotary Drum Test was measured by slide calipers and found $0.05-0.13 \mathrm{~mm}$, which might be considered as negligible. The corrosion resistance of alumina-zirconia-mullite could be related to the unique micro-structural features, which was consisted of interlocking of mullite crystals and the glassy phase with the most insoluble $\mathrm{ZrO}_{2}$ crystals, resulting in a low rate of dissolution of $\mathrm{Al}_{2} \mathrm{O}_{3}, \mathrm{SiO}_{2}, \mathrm{Na}_{2} \mathrm{O}$ and $\mathrm{CaO}$ at the end of the interface region. Analyzing readings with compositions it has been found that the corrosion resistance was adversely affected with $\mathrm{TiO}_{2}$ addition as it resulted in the reduction of corundum and zirconia phase in the microstructure (Fig. 11).

From SEM studies (Fig. 12) of the sintered compacts it has been found that. mullite exhibited equi-axed grains in the higher alumina containing batches and mixed (acicular and equiaxed) grains in the lower alumina batches. The zirconia grains were distributed throughout the mullite matrix. Two types of zirconia grains were observed to be present; one is inter-granular $\mathrm{t}-\mathrm{ZrO}_{2}$ located between the mullite grains and the other one is intra-granular $\mathrm{t}-\mathrm{ZrO}_{2}$ located inside the mullite grains. Intra-granular ones are much smaller than the inter-granular ones (almost 4 folds bigger than intra-granular grains). The presence of a liquid (or glass) highly facilitates the growth of inter-granular $\mathrm{ZrO}_{2}$ grains. It has also studied the effect of the growth the crystallite size with increase in temperature $\left(1450\right.$ and $\left.1550{ }^{\circ} \mathrm{C}\right)$ and soaking time (3-5 h). The average crystallite size was calculated using DebyeScherrer formula [17] as follows:

$$
\mathrm{D}=\mathrm{K} \cdot \lambda /(\mathrm{B} \cdot \cos \theta)
$$

where $\mathrm{D}$ is the diameter of the crystallites forming the film, $\mathrm{K}$ is the Scherrer constant (value assumed 0.89), $\lambda$ is the wavelength of $\mathrm{Cu}-\mathrm{k} \alpha$ line (value assumed 1.54 Angstrom), $\beta$ is FWHM in radian, and $\theta$ is the Bragg angle

$$
\beta=\sqrt{\left(\beta_{0}^{2}-b^{2}\right)}
$$

where $\beta o$ is the FWHM in radians for the sample and $\mathrm{b}$ the FWHM in radians for the pure crystal. The average crystallite size of mullite was found to increase with soaking time and temperature (Fig. 13). While comparing the same where
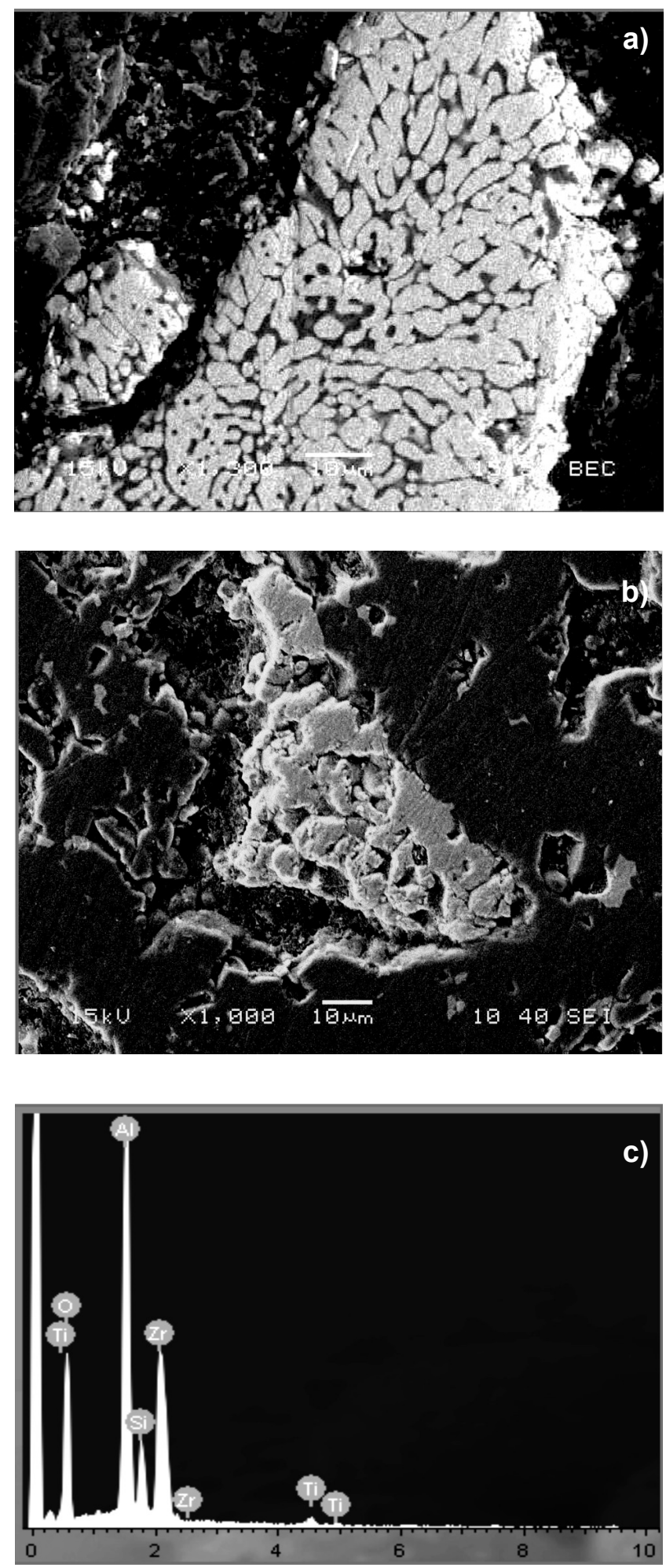

Figure 12: SEM and EDX image of the sintered compact (Batch 2) showing intra and inter-granular zirconia, acicular shaped mullite precipitated out from aluminum titanate liquid and zirconia toughened matrix showing compact microstructure.

[Figura 12: MEV e EDX imagem do compacto sinterizado (lote 2) mostrando a zircônia intra e inter-granular, precipitado de mulita em forma acicular para fora do liquido do titanato de alumínio mostrando a microestrutura compacta da matriz endurecida da zircônia.] 


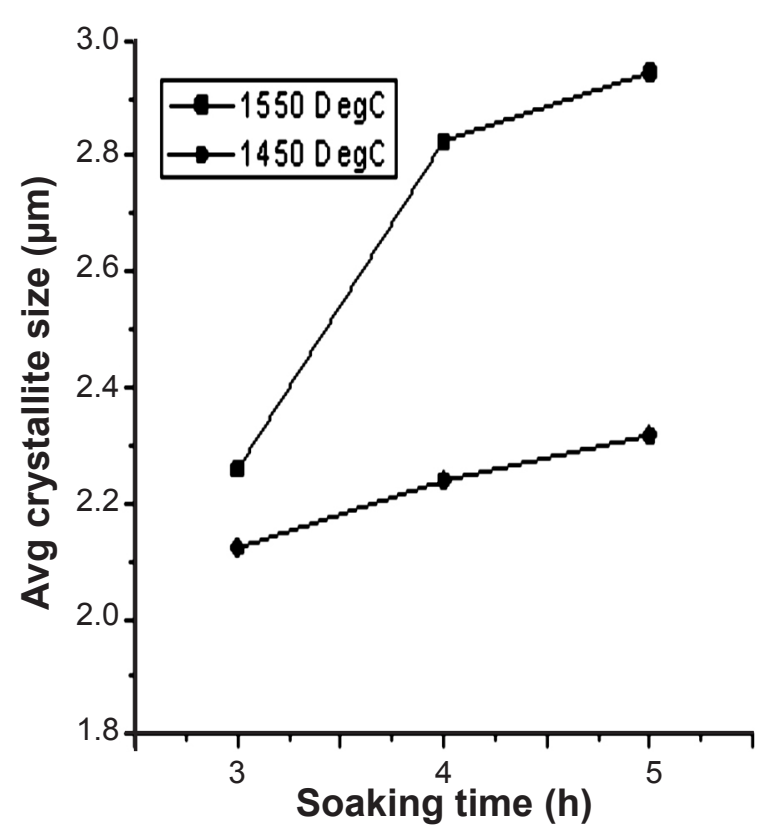

Figure 13: Average crystallite size of mullite increasing with temperature and soaking hour with presence of titania as additive. [Figura 13: Tamanho médio do cristalito de mulita com aumento da temperatura e hora de imersão com a presença de titânia como aditivo.]

additive was not used, smaller crystallite size was observed at the same temperature and soaking time. It indicates the grain growth of mullite in presence of $\mathrm{TiO}_{2}$ as additive.

\section{CONCLUSION}

Titania as an additive played significant role within a pertain limit on the formation and physico-mechanical properties of reaction sintered isostatically pressed zirconiamullite composites. A part of alumina remained combined with $\mathrm{TiO}_{2}$ in the form of aluminum titanate phase.

Although properties like, bulk density, reduction in apparent porosity and hardness were improved with the increase in $\mathrm{TiO}_{2}$ content, with higher proportion of $\mathrm{TiO}_{2}$, modulus of rupture and corrosion resistance values decreased due to reduced interlocked mullite content. The microstructures of the sintered samples were consisted of both inter-granular and intra-granular $\mathrm{t}-\mathrm{ZrO}_{2}$.

\section{REFERENCES}

[1] N. Claussen, J. Jahn, J. Am. Ceram. Soc. 63, 3-4 (1980) 228-229.

[2] P. Boch, T. Chartier, P. D. D. Rodrigo, J. Am. Soc. Proc. 6 (1923) 353-374.

[3] P. Descamps, S. Sakaguchi, M. Poorteman, F. Cambier, J. Am. Ceram. Soc. 74, 10 (1991) 2476-2481.

[4] H. S. Tripathi, S. K. Das, B. Mukherjee, A. Ghosh, G. Banerjee, Ceram. Int. 27, 8 (2001) 833-837.

[5] L. B. Garrido, E. F. Aglietti, Ceram. Int. 5 (2001) 491499.

[6] F. Temoche, L. B. Garrido, E. F. Aglietti, Ceram. Int. 31, 7 (2005) 917-922.

[7] C. Aksel, Ceram. Int. 29, 3 (2003) 311-316.

[8] K. Das, G. Banerjee, J. Eu. Ceram. Soc. 20, 2 (2000) 153-157.

[9] N. M. Rendtorff, L. B. Garrido, E. F. Aglietti, Ceram. Int. 34, 8 (2008) 2017-2024.

[10] C. Ozturk, Y. K. Tur, J. Eu. Ceram. Soc. 27, 2-3 (2007) 1463-1467.

[11] T. Ebadzadeh, E. Ghasemi, Ceram. Int.. 28, 4 (2002) 447-450.

[12] K. Das, B. Mukherjee, G. Banerjee, J. Eu. Ceram. Soc. 18, 12 (1998) 1771-1777.

[13] M. F. Melo, J. S. Moya, P. Pena, S. De Aza, J. Mater. Sci. 20 (1985) 2711-2718.

[14] S. Maitra, A. Rahaman, A. Sarkar, A. Tarafdar, Ceram. Int. 32, 2 (2006) 201-206.

[15] M. Hamidouche, N. Bouaouadja H. Osmani, R. Torrecilliasb, G. Fantozzi, J. Eur. Ceram. Soc. 16 (1996) 441-445.

[16] M. R. Anseau, C. Leblud, F. Cambier, J. Mater. Sci. Lett. 2 (1983) 366-370.

[17] B. D. Cullity, "Elements of X-ray diffraction”, AddisonWesley Publ. Co. Inc., USA (1959) p. 59.

[18] P. Pena, S. de Anza, La Ceramica 30 (1977) 1-6.

[19] P. Pena, S. de Anza, La Ceramica 12 (1983) 201-202.

(Rec. 13/07/2012, Ac. 05/05/2013) 